\title{
EFFECT OF SUPPLEMENTATION OF F100 BISCUITS MODIFIED WITH MORINGA OLEIFERA FLOUR SUBSTITUTION ON NUTRITIONAL STATUS OF UNDER-FIVE CHILDREN WITH MALNUTRITION IN KENDARI CITY INDONESIA
}

\author{
Riska Mayangsari ${ }^{1 *}$, Ketut Rasmiati ${ }^{2}$ \\ ${ }^{1}$ S1 Gizi Study Program, STIKes Karya Kesehatan, Indonesia \\ ${ }^{2}$ S1 Keperawatan Study Program, STIKes Karya Kesehatan, Indonesia
}

Received: 13 December 2019 | Accepted: 7 March 2020

DOI: http://dx.doi.org/10.36685/phi.v6i1.318

\author{
Correspondence: \\ Riska Mayangsari \\ STIKes Karya Kesehatan, Indonesia \\ Jl. Jend AH Nasution No 89 Anduonohu, Kendari City, 93232, Indonesia \\ Email: riska.mayangsari28@gmail.com
}

Copyright: (C) 2020 the author(s). This is an open-access article distributed under the terms of the Creative Commons Attribution Non-Commercial License, which permits unrestricted non-commercial use, distribution, and reproduction in any medium, provided the original work is properly cited.

\begin{abstract}
Background: Malnutrition is a condition of severe nutritional deficiency caused by an insufficient intake of energy and protein from daily food consumption. The most lethal impacts are declined IQ score, decreased cognitive development, and diminished sensory integration, which could harm the life of the children and resulted in the loss of the national youth generation. One effort to overcome this problem is to develop a diet alternative using F100 materials substituted from kelor (Moringa Oleifera) flour as the main ingredient and reform it into edible biscuits. Kelor leaves contain multiple micronutrient elements that are essential for children and have been proven to increase the nutritional status of children with malnutrition.

Objective: This research aims to identify the effect of the supplementation of F100 biscuits modified with kelor flour substitution on the nutritional status of under-five children with malnutrition.

Methods: This was a pre-experimental study conducted in Kendari city Indonesia from May-June 2019. Twenty children were included and given modified biscuits on a scale of 100 gm per day for six consecutive weeks. Data were analyzed using dependent and independent sample t-test.

Results: There was a significant effect of the supplementation of F100 modified biscuits on the nutritional status of under-five children with malnutrition $(p=0.002)$.

Conclusion: The F100 supplementation modified with kelor flour substitution biscuits has been proven to be effective in increasing the nutritional status of under-five children with malnutrition.
\end{abstract}

Keywords: biscuit, F100, kelor, malnutrition, children, moringa oleifera

\section{BACKGROUND}

Nutritional status is one of the factors determining the quality of human resources. Toddlers are one of the groups that are more susceptible to health problems, especially if their nutritional consumption are unbalanced with the standard their body needed. This situation potentially leads to nutritional complications (Mardalena, 2017; $\underline{\text { Sahu et al., 2015; Yisak, Gobena, \& Mesfin, }}$ 2015).

Malnutrition is a condition of severe nutritional deficiency caused by insufficient energy and protein intake from daily food consumption that happened in long terms. The short-term effect of 
malnutrition includes apathy, speech disorder, and growth disorder in children. Furthermore, the long terms effects are including the decline in IQ score, a decrease of cognitive development, and diminish sensory integration which could harm the life of the children and resulted in the loss of the National young generation (Almatsier, 2009; Venables \& Raine, 2016).

The result of nutritional status assessment in 2016 using the weight/height index of children 0-59 months in Indonesia revealed the percentage of $3.4 \%$ for malnutrition in Indonesia (Kementerian Kesehatan Republik Indonesia, 2017). There is not a single area in Sulawesi Tenggara that is free from malnutrition. Most of the areas presented 20 incidents/area on average, including Kendari city (Dinas Kesehatan Sultra, 2017). To accelerate the malnutrition elimination program in Indonesia, apart from the food diversification program, it is also important to develop a formula for food supplementation contains standardized nutrients to increase child immunity, and also to generate a food processing technology that sustains the excellence of local food resources (Osendarp et al., 2015; Zakaria, Lestari, \& Hartono, 2013).

F100 is a food formula contains energy, fat, and high proteins recommended by WHO to treat children with malnutrition (Bhandari, 2016; Fekadu, Mesfin, Haile, \& Stoecker, 2015; Lanyero et al., 2017). However, F100 supplementation to children with malnutrition still facing some obstacles, e.g. sanitation during food processing and hygiene of the tools that are being used (Ambarwati, Setiadi, Tursilowati, \& Rahmawati, 2018). F100 supplementation in unhygienic conditions could give rise to bacterial pathogens to grow. Therefore, there needs to be a development of food materials that contain good nutrients, highly bioavailable, relatively procurable, and economically convenient. The potential alternative is the production of biscuits as a form of extra food using F100 substituted with Kelor flour as the main ingredient (Kholidah, Prawirohartono, \& Nisa, 2013).

Biscuit is one type of food widely consumed in different forms by all ages, from babies to adults (Sari, 2013). Moreover, kelor is a type of plant commonly found in Kendari City. It is already integrated into the culinary culture of Sulawesi Tenggara Province, and people often consume it as vegetables. Kelor leaves contain multiple micronutrients that are essential for babies and pregnant woman, such as beta carotene, thiamin (B1), riboflavin (B2), niacin (B3), calcium, iron, phosphor magnesium, zinc, dan vitamin C ( $\mathrm{Daba}_{\text {, }}$ 2016; Rudianto \& Alharini, 2013; ShM, Kassim, AbouRayya, \& Abdalla, 2017). Kelor is recommended to be transformed into flour because this form is more durable and easy to store (Jerri, Adolfsen, McCullough, Velegol, \& Velegol, 2012; Kusharto \& Damayanthi, 2017). The nutritional content of kelor will be increased in quantity if it is consumed after being dried and made into flour (Adwiyah, 2016; Bolarinwa, Aruna, \& Raji, 2019; Singh \& Prasad, 2013). Another benefit of kelor is to increase the nutrient status of children with malnutrition (Dhakar, Maurya, Pooniya, Bairwa, \& Gupta, 2011; Gopalakrishnan, Doriya, \& Kumar, 2016; Rahmawati \& Adi, 2016).

There has been a lot of precedent research that studies the effect of adding kelor leaves supplement formula into food products to increase the food nutritional value, for example in biscuits, soy meatballs, and yogurt (Diantoro, Rohman, Budiarti, \& Palupi, 2015; Evivie, Ebabhamiegbebho, Imaren, \& Igene, 2015; Kholis \& Hadi, 2010). Transforming the kelor leaves into biscuits will increase its likeability among people, which in turn is expected to increase the consumption of kelor leaves in society. Therefore, all the benefits contain by the kelor leaves will be absorbed by the body (Rahmawati \& Adi, 2016). This study aimed to examine the effect of supplementation of F100 biscuits modified with kelor flour substitution on nutritional status of children with malnutrition in Kendari city Indonesia.

\section{METHODS}

\section{Study Design and Participants}

This was a pre-experimental study conducted in Kendari city Indonesia from May-June 2019. The participants in this study were 20 under-five children with malnutrition in Kendari city. The 
exclusion criterion was children with malnutrition but experiencing medical complications.

\section{Instrument}

The instruments in this study included digital scales, microtoise, and biscuit intake recording form. WHO Anthro 2005 application was used to measure children's nutritional status, and Nutrisurvey 2007 was used to measure food and biscuits consumption.

\section{Intervention}

The supplementation of F100 biscuits modified with kelor flour substitution were explained in the following:

a. Tools and material. The main ingredient used in this study was moringa flour of Southeast Sulawesi, while other supplementary ingredients included wheat flour, egg yolks, refined sugar, margarine, skimmed milk powder, vanilla, and salt. Tools included blenders, 80 mesh sieves, mixers, biscuit molds, ovens, wood rollers, basins, spoons, brushes, and food scales.

b. Making moringa flour. The production of moringa leaf flour used a dry blender and was sieved using 80 mesh sieves to separate small stems that cannot be destroyed with a blender, then stored in an airtight plastic container (Rudianto \& Alharini, 2013; Zakaria et al., 2013).

c. Making biscuits. Biscuits were made with mixing ingredients including flour (500 gr), sugar (250 gr), margarine (400 gr), egg yolks ( 3 grains), followed by mixing until they were fused, then added moringa flour to the ratio according to the treatment that was $5 \mathrm{~g}, 10 \mathrm{~g}$, $15 \mathrm{~g}$, and $20 \mathrm{~g}$ and powdered skim milk (70 gr), salt ( 2 gr) and vanilla (4 gr), then gradually stirred with a mixer for about 30 minutes until the mixture was mixed equally. The obtained dough was then molded into 4 shapes according to the number of treatments and baked in an oven at $160{ }^{\circ} \mathrm{C}$ for 20 minutes.

d. Organoleptic test included texture, aroma, color, and taste of the modified F100 biscuit product in each treatment to determine the F100 modified biscuit product most preferred by the panelists. Assessment scores were given based on hedonic test criteria from selected 23 trained panelists. The results of this study indicated that according to the level of preference of the F100 biscuit modification product panelists with the addition of moringa flour which was preferred by the panelists, was the formula R2 with the addition of 10 grams of moringa flour.

e. Nutrition content analysis included protein content analyzed by the Kjeldahl method, fat by the Soxhlet method, carbohydrates by the difference method, water content by the oven method, ash content by the drying ash method. The results of the analysis of the nutritional content of biscuits based on panelist choices were biscuits with the addition of 10 grams of moringa flour showed that the calorie value was $429.6 \mathrm{kcal}$, protein $25.63 \mathrm{gr}$, fat $33,71 \mathrm{gr}$, carbohydrate 101.56 gr, water content $3,45 \%$, and ash content $1.51 \%$.

f. Giving biscuits to malnourished children. The amount of modified F100 biscuits consumed daily for 6 weeks including how much was given, the amount consumed, and the remaining amount. Data on the amount of intake were recorded on the receipt form. Determination of the frequency of giving F100 modified biscuits to all samples was calculated based on body weight per individual, condition of the toddler at the time of examination and according to energy requirements, protein per individual for 6 weeks. Given after breastfeeding for infants who were still breastfed, or given before family feeding for children who received the main food.

\section{Data Analysis}

Data were analyzed using dependent and independent sample t-test using the SPSS program.

\section{Ethical Consideration}

This study was approved by the Research Ethics Committee of IAKMI Pengda Sultra with number: 003/ KEPK-IAKMI/ V/ 2019. An informed consent was signed by each participant in this study.

\section{RESULTS}

The majority of children were boys ( $n=11,55 \%)$ than girls $(n=9,45 \%)$, with the average age of 
46.50 months $(\mathrm{SD}=7.008)$ with malnutrition status. Nutritional intake of children was obtained from daily food consumption in the sum of breakfast, lunch, dinner and snack. Table 1 shows that the average of energy intake of the participants before given biscuits was 854.21 calories, and after given biscuits was 1006.15 calories. The average protein intake before given biscuits was 9.72 grams, and after given biscuits was 15.09 gr. Statistical test results showed there were significant differences in the increase in energy and protein intake after consuming F100 biscuits modified with kelor flour substitution.

Table 1 The Average Energy and Protein Intake Before and After the Intervention

\begin{tabular}{lccc}
\multicolumn{4}{c}{ After the Intervention } \\
\hline Nutrient & Pretest & Posttest & P-value \\
\hline Energy (Kal) & 854.21 & 1006.15 & 0.000 \\
Protein (g) & 9.72 & 15.09 & 0.000 \\
\hline
\end{tabular}

Table 2 The Level of Biscuits Consumption

\begin{tabular}{lcc}
\hline Consumption level & n & $\mathbf{\%}$ \\
\hline Insufficient $(<50 \%)$ & 5 & 25 \\
Sufficient $(>50 \%)$ & 15 & 75 \\
Total & 20 & 100 \\
\hline
\end{tabular}

The children's consumption level was observed from the number of biscuits that had been consumed for 6 weeks, which was divided into the number of biscuits supposed to be consumed ( 252 pieces). The level of consumption of children is categorized "sufficient" when spending biscuits as many as $\geq 126$ pieces, while the level of consumption of children is categorized as "insufficient" if children consumes biscuits as $<126$ pieces. Table 2 shows that 15 children $(75 \%)$ had sufficient consumption level of biscuits, and 5 children (25\%) had insufficient level of biscuit consumption.

Table 3 Effect of supplementation of F100 modified with kelor flour substitution biscuit on nutritional status of children Consumption level

\begin{tabular}{|c|c|c|c|}
\hline \multirow[t]{3}{*}{ Consumption level } & \multicolumn{2}{|c|}{ Final nutritional status } & \multirow[t]{3}{*}{$p$-value } \\
\hline & Malnutrition & Undernutrition & \\
\hline & $\%$ & $\%$ & \\
\hline Insufficient & 10 & 15 & \\
\hline Sufficient & 5 & 70 & 0.002 \\
\hline Total & 15 & 85 & \\
\hline
\end{tabular}

Table 3 shows that there was a change in nutritional status in children. Before the intervention, all children were in malnutrition status, but after given the intervention, the status was changed from malnutrition to undernutrition specifically for the children who had sufficient consumption level of biscuits $(70 \%)$. However, for those who had insufficient level of biscuit consumption, only $15 \%$ of children were changed from malnutrition to undernutrition. The statistical test showed that there was a significant effect of giving the supplementation of F100 biscuits modified with kelor flour substitution on the nutritional status of children under five with $\mathrm{p}$ value of 0.002 .

\section{DISCUSSIONS}

Nutrient contribution of F100 substituted with kelor biscuits to the nutrient sufficiency range of the children

The number of biscuits consumed by children was 6 pieces or equivalent to $100 \mathrm{~g}$ per day. On average, the contribution of energy from biscuits was above $10 \%$ of nutrient range, which was $10.9 \%$ from the total. Meanwhile, the average proportion of protein contribution from biscuit consumption was $21.48 \%$ of nutrient range. According to BPOM, food is categorized as a good source of protein if it contains at least $20 \%$ of nutrient range recommended per serving (Badan Pengawas Obat dan Makanan, 2014). Additional food supplementation (AFS, or PMT in Bahasa Indonesia) for recovery purposes is one of the efforts to handle malnutrition problems. PMT is a diet capable of providing an extra beneficial effect for health besides the nutritional elements that naturally contained in food (Chaix, Zarrinpar, Miu, \& Panda, 2014). PMT given to children with malnutrition intend to gradually provide a good and enough protein, vitamin, and mineral intake to achieve optimal nutritional status with sufficient nutritional composition.

\section{Biscuit intake level}

The children's consumption level could be observed from the number of biscuits taken in 6 weeks divided into the number of biscuits supposed to be consumed (252 pieces). In this 
study, $75 \%$ of the children had enough level of consumption, and only $25 \%$ of the children had an insufficient level of consumption. Based on the interview with the mothers, the children enjoyed the biscuits for the good flavor. On the other hand, the children in category middle level of consumption became disinterested with the biscuits in weeks 4 and 5. This disinterest feeling resulted from the preference of the children who had to consume 6 pieces of biscuits with the same form and flavors for 6 weeks consecutively. As a result, the children who were initially able to finish 6 biscuits per day in the first weeks, eventually could only take 1-2 pieces of biscuits per day in week 4 to week 5 .

Another potential explanation was that the condition of the children that were sick at the moment they were being assessed. During the study, 6 children experienced sickness with common types of symptoms like fever, cough, and flu. This condition could affect the appetite of the children which in turn affects the intake level of the biscuits

The effect of supplementation of F100 modified with kelor flour substitution biscuit on the nutritional status of children

F100 modified with kelor flour substitution biscuit is a type of snack made from several ingredients, including the main element of kelor flour with certain nutrient levels to achieve a high level of nutrition. kelor flour consumption is one of the alternatives to increase the weight of children with malnutrition. This study shows that there was an increase of nutritional status from malnutrition to undernutrition to those who had sufficient level of biscuit consumption. This result is in line with a study conducted an experiment of PMT-P supplementation in form of Tempe biscuits for 1 month to 17 children with tuberculosis aged 12-59 months (Muslimah, Judiono, Suparman, Ichwannudin, \& Diandini, 2019).

The result of statistical analysis displayed the significant effect of supplementation of F100 modified with kelor flour substitution biscuit to the nutritional status of children. This means that the larger portion of children with enough intake of F100 modified biscuits had better nutritional status $(70 \%)$. On the other hand, the children with low intake of F100 modified biscuits had lower nutritional status (15\%), This could indicate that biscuit consumption according to the recommendation could increase the nutritional status of the children. This result is due to the high level of energy contribution and protein from the biscuit intake resulted from the addition of kelor flour in the biscuits.

This is in line with the theory stated that the more kelor flour added, the higher the level of protein, iron, calcium, fiber content, and $\beta$-carotene in the food. This indicates the potential of kelor flour is used to increase the nutrient level in foods (Dachana, Rajiv, Indrani, \& Prakash, 2010). The digestibility of amino acid and protein is up to $60 \%$, increasing the ability of nutritional absorption contained in kelor flour (Baptista et al., 2017). This result is in line with previous study that that the weight of the children administered with kelor flour intake was higher than the unadministered children $(8.9 \pm 4.30 \mathrm{~g} / \mathrm{kg} / \mathrm{days}$ compared to $5.7 \pm 2.72 \mathrm{~g} / \mathrm{kg} /$ days $)$, and faster recovery rate with the average of $36 \pm 16.54$ days for administered children compared to $57 \pm 19.20$ days in unadministered children (Zongo, Zoungrana, Savadogo, \& Traoré, 2013)

\section{CONCLUSION}

The supplementation of F100 modified with kelor flour substitution biscuits increases the nutritional status of children with malnutrition. This study can be an input as an alternative treatment to increase the nutritional status of under-five children with malnutrition. Future studies with control groups were needed to see the effectiveness of this intervention on nutritional status of the children.

\section{Declaration of Conflicting Interest}

There is no conflict of interest in this study.

Acknowledgment

The authors delivered the deepest gratitude to all parties that helped this research.

REFERENCES

Adwiyah, A., Melani, V., \& Fadhila, R. (2016). Uji Daya Terima, Nilai Gizi dan Analisis Jumlah Bakteri Pada Produk Mi Kering Dengan Penambahan 
Tepung Daun Kelor. Theses. Universitas Esa Unggul, Jakarta.

Almatsier, S. (2009). Prinsip Dasar Ilmu Gizi, Jakarta: PT. Gramedia Pustaka Utama.

Ambarwati, R., Setiadi, Y., Tursilowati, S., \& Rahmawati, A. Y. (2018). Pelatihan pembuatan crackers modifikasi f100 dengan substitusi tepung labu kuning bagi tenaga gizi pendamping gizi buruk. LINK, 14(1), 22-25.

Badan Pengawas Obat dan Makanan. (2014). Peraturan kepala Badan Pengawas Obat dan Makanan Republik Indonesia nomor 12 tahun 2014 tentang persyaratan mutu obat tradisional: Badan Pengawas Obat dan Makanan Republik Indonesia.

Baptista, A. T. A., Silva, M. O., Gomes, R. G., Bergamasco, R., Vieira, M. F., \& Vieira, A. M. S. (2017). Protein fractionation of seeds of Moringa oleifera lam and its application in superficial water treatment. Separation and Purification Technology, 180, 114124.

Bhandari, N. (2016). Infant and Young Child Feeding. Proceedings of the Indian National Science Academy, 82(5), 1507-1517.

Bolarinwa, I. F., Aruna, T. E., \& Raji, A. O. (2019). Nutritive value and acceptability of bread fortified with moringa seed powder. Journal of the Saudi Society of Agricultural Sciences, 18(2), 195-200.

Chaix, A., Zarrinpar, A., Miu, P., \& Panda, S. (2014). Timerestricted feeding is a preventative and therapeutic intervention against diverse nutritional challenges. Cell metabolism, 20(6), 991-1005.

Daba, M. (2016). Miracle tree: A review on multi-purposes of Moringa oleifera and its implication for climate change mitigation. Journal of Earth Science and Climate Change, 7(4).

Dachana, K., Rajiv, J., Indrani, D., \& Prakash, J. (2010). Effect of dried moringa (Moringa oleifera lam) leaves on rheological, microstructural, nutritional, textural and organoleptic characteristics of cookies. Journal of Food Quality, 33(5), 660-677.

Dhakar, R. C., Maurya, S. D., Pooniya, B. K., Bairwa, N., \& Gupta, M. (2011). Moringa: The herbal gold to combat malnutrition. Chronicles of Young Scientists, 2(3), 119.

Diantoro, A., Rohman, M., Budiarti, R., \& Palupi, H. T. (2015). Pengaruh penambahan ekstrak daun kelor (Moringa Oleifera L.) terhadap kualitas yoghurt. TEKNOLOGI PANGAN: Media Informasi dan Komunikasi Ilmiah Teknologi Pertanian, 6(2).

Dinas Kesehatan Sultra. (2017). Profil Kesehatan Sulawesi Tenggara.

Evivie, S., Ebabhamiegbebho, P., Imaren, J., \& Igene, J. (2015). Evaluating the organoleptic properties of soy meatballs (BEEF) with varying levels of Moringa oleifera leaves powder. Journal of Applied Sciences and Environmental Management, 19(4), 649-656.

Fekadu, Y., Mesfin, A., Haile, D., \& Stoecker, B. J. (2015). Factors associated with nutritional status of infants and young children in Somali Region, Ethiopia: a cross-sectional study. BMC Public health, 15(1), 846.
Gopalakrishnan, L., Doriya, K., \& Kumar, D. S. (2016). Moringa oleifera: A review on nutritive importance and its medicinal application. Food Science and Human Wellness, 5(2), 49-56.

Jerri, H. A., Adolfsen, K. J., McCullough, L. R., Velegol, D., \& Velegol, S. B. (2012). Antimicrobial sand via adsorption of cationic Moringa oleifera protein. Langmuir, 28(4), 2262-2268.

Kementerian Kesehatan Republik Indonesia. (2017). Profil Kesehatan. Kementerian Kesehatan Republik Indonesia

Kholidah, D., Prawirohartono, E. P., \& Nisa, F. Z. (2013). Pemberian makanan F100 dengan bahan substitusi tepung tempe terhadap status protein pasien anak dengan gizi kurang. Jurnal Gizi Klinik Indonesia, 10(2), 92-100.

Kholis, N., \& Hadi, F. (2010). Pengujian bioassay biskuit balita yang disuplementasi konsentrat protein daun kelor (Moringa oleifera) pada model tikus malnutrisi. Jurnal Teknologi Pertanian, 11(3), 144-151.

Kusharto, C. M., \& Damayanthi, E. (2017). Pengembangan crackers sumber protein dan mineral dengan penambahan tepung daun kelor (Moringa oleifera) dan tepung badan-kepala ikan lele dumbo (Clarias gariepinus). Nutri-Sains: Jurnal Gizi, Pangan dan Aplikasinya, 1(1), 22-38.

Lanyero, B., Namusoke, H., Nabukeera-Barungi, N., Grenov, B., Mupere, E., Michaelsen, K. F., . . . Briend, A. (2017). Transition from F-75 to ready-to-use therapeutic food in children with severe acute malnutrition, an observational study in Uganda. Nutrition Journal, 16(1), 52.

Mardalena, I. (2017). Dasar-Dasar Ilmu Gizi Dalam Keperawatan: Konsep dan Penerapan Pada Asuhan Keperawatan. Yogyakarta: Pustaka Baru Press.

Muslimah, H. Z., Judiono, J., Suparman, S., Ichwannudin, I., \& Diandini, A. K. (2019). Peranan Pemberian Cookies Kedelai Mocaf Terhadap Peningkatan Berat Badan Balita Gizi Kurang. Jurnal Riset Kesehatan Poltekkes Depkes Bandung, 11(2), 92101.

Osendarp, S., Rogers, B., Ryan, K., Manary, M., Akomo, P., Bahwere, P., . . . Dibari, F. (2015). Ready-to-use foods for management of moderate acute malnutrition: considerations for scaling up production and use in programs. Food and Nutrition Bulletin, 36(1_suppl1), S59-S64.

Rahmawati, P. S., \& Adi, A. C. (2016). Daya terima dan zat gizi permen jeli dengan penambahan bubuk daun kelor (Moringa oleifera). Media Gizi Indonesia, 11(1), 86-93.

Rudianto, S., \& Alharini, S. (2013). Studi Pembuatan Dan Analisis Zat Gizi Pada Produk Biskuit Moringa Oleifera Dengan Subtitusi Tepung Daun Kelor. Program Studi Ilmu Gizi Fakultas Kesehatan Masyarakat Universitas Hasanuddin Makasar.

Sahu, S. K., Kumar, S. G., Bhat, B. V., Premarajan, K., Sarkar, S., Roy, G., \& Joseph, N. (2015). Malnutrition among under-five children in India and strategies for control. Journal of Natural Science, Biology, and Medicine, 6(1), 18. 
Sari, O. (2013). Formula Biskuit Kaya Protein Berbasis Spirulina dan Kerusakan Mikrobiologis Selama Penyimpanan.[Skripsi]. Program Studi Teknologi Hasil Perairan.

ShM, T., Kassim, N., AbouRayya, M., \& Abdalla, A. (2017). Influence of foliar application with Moringa (Moringa oleifera L.) leaf extract on yield and fruit quality of hollywood plum cultivar. Journal of Horticulture, 4(193), 2376-0354.1000193.

Singh, Y., \& Prasad, K. (2013). Moringa oleifera leaf as functional food powder: Characterization and uses. International Journal of Agriculture and Food Science Technology, 4(4), 317-324.

Venables, P. H., \& Raine, A. (2016). The impact of malnutrition on intelligence at 3 and 11 years of age: The mediating role of temperament. Developmental Psychology, 52(2), 205.

Yisak, H., Gobena, T., \& Mesfin, F. (2015). Prevalence and risk factors for under nutrition among children under five at Haramaya district, Eastern Ethiopia. BMC Pediatrics, 15(1), 212.

Zakaria, A. T., Lestari, R., \& Hartono, R. (2013). Pemanfaatan Tepung kelor (Moringa Oleifera) Dalam Formulasi Pembuatan Makanan Tambahan Untuk Balita Gizi Kurang. Media Gizi Pangan.

Zongo, U., Zoungrana, S. L., Savadogo, A., \& Traoré, A. S. (2013). Nutritional and clinical rehabilitation of severely malnourished children with Moringa oleifera Lam. leaf powder in Ouagadougou (Burkina Faso).

Cite this article as: Mayangsari, R., Rasmiati, K. (2020). Effect of supplementation of F100 biscuits modified with moringa oleifera flour substitution on nutritional status of under-five children with malnutrition in Kendari city Indonesia. Public Health of Indonesia. 6(1), 28-34. http://dx.doi.org/10.36685/phi.v6i1.318 